\section{FAKTOR-FAKTOR YANG BERHUBUNGAN DENGAN KETERLAMBATAN PENANGANAN KANKER PAYUDARA STADIUM III \&IV DI POLIKLINIK ONKOLOGI RSUD PROVINSI NTB 2018}

\section{Factors Associated with Delay Management of Stage III \& IV Breast Cancer Treatment at The Oncology Polyclinic of The NTB Provincial Hospital 2018}

\section{Misroh Mulianingsih"1, Ilham ${ }^{1}$, Irwan Hadi', Meyka Aris Yusron², Zuliardi', Dwitya Citta $\mathbf{P}^{1}$, Hayana ${ }^{1}$}

1. STIKes Yarsi Mataram

2. Mataram University Hospital

\section{Riwayat artikel \\ Diajukan: 25 Mei 2021 \\ Diterima: 9 Agustus 2021}

\section{Penulis Korespondensi:}

- Misroh Mulianingsih

- STIKES Yarsi Mataram e-mail:

misroh.yarsi@gmail.com

\section{Kata Kunci:}

Pengelolaan Keterlambatan Pengobatan, Penderita Kanker Payudara Stadium III dan IV

\section{Abstrak}

Pendahuluan : Payudara merupakan tempat nomor satu tumbuhnya kanker pada wanita. Kanker payudara paling banyak menyerang perempuan dan pada stadium awal, jika diraba, umumnya tidak menemukan adanya benjolan yang jelas pada payudara. Namun sering merasakan ketidaknyamanan pada daerah tersebut sehingga sering terlambatnya pasien dalam pengobatan kanker payudara. Tujuan: untuk mengetahui factor yang berhubungan dengan pengelolaan keterlambatan pengobatan pada penderita kanker payudara stadium III \& IV di RSUD Provinsi NTB 2018. Metode:desain Penelitian adalah analitik korelasional restrospektif dengan jumlah sampel 35 orang. Penelitian ini dilakukan di Poliklinik Onkologi RSUD Provinsi NTB pada bulan Januari 2019. Instrument yang digunakan yaitu dengan menggunakan kuesioner. Hasil: hasil penelitian menunjukkan bahwa keterlambatan terjadi pada responden dengan pendidikan SD sebanyak 11 (31.4\%) dengan kriteria tidak mampu pada sosial ekonomi sebanyak 21 (60\%). Responden yang memiliki psikologik yang cukup sebanyak 29 (82.8).Responden yang mendapatkan rujukan $\leq 30$ Hari sejak pemeriksaan sebanyak $18(51.4 \%)$, dan responden yang mendapatkan diagnosis $\leq 30$ hari sebanyak 25 $(71.4 \%)$. Responden yang mendapatkan rujukan $\leq 30$ Hari sejak pemeriksaan sebanyak $21(60 \%)$, responden yang mendapatkan kemoterapi pertama $\leq 20$ hari sejak diagnosis sebanyak $29(82.9 \%)$ dan responden yang mendapatkan rentang waktu dari kemoterapi pertama ke kemoterapi kedua $\leq 30$ hari sebanyak 26 (74.3\%). Kesimpulan: Rekomendasi yang dapat diberikan adalah melakukan sosialisasi/ penyuluhan kepada masyarakat mengenai kanker payudara ini.

\begin{abstract}
Background: The breast is the most common organ for cancer in women. Breast cancer most commonly affects women and in the early stages, if palpated, generally do not find a clear lump in the breast. But often feel discomfort in the area so that patients are often late in breast cancer treatment. Objective: This study aims to determine the factors associated with managing treatment delays in patients with breast cancer stage III \& IV at the NTB Provincial Hospital in 2018. Method: The study design was a retrospective correlational analysis with a sample size of 35 people. They conducted at the Oncology Polyclinic of the NTB Provincial Hospital in January 2019 by using a questionnaire. Results: Based on the study results, know that delays occurred in respondents with elementary education as many as 11 (31.4\%) with 21 (60\%) socio-economic incapacity criteria. Respondents who had sufficient psychology were 29 (82.8). Respondents who received referrals $\leq 30$ days from the examination were 18 (51.4\%), and respondents who received a diagnosis of $\leq 30$ days were 25 (71.4\%). Respondents who received referrals $\leq 30$ days from the examination were 21 (60\%), respondents who received first chemotherapy $\leq 20$ days from diagnosis were 29 (82.9\%), and respondents who received time ranges from first chemotherapy to second chemotherapy $\leq 30$ days were 26 ( 74.3\%). Conclusion: Recommendations that can give are to do socialization/counselling to the public about this breast cancer..
\end{abstract}




\section{INTRODUCTION}

The breast is the most common organ for cancer in women(American Cancer Society, 2017). Breast cancer is the most common malignancy in women and originates from the cells and ducts of the glands and other breast tissues, except for their skin(Anzic \& Marinko, 2020; (Depkes RI, 2009).

The most common cancer in women is breast cancer. Because the number of new cases was around 1.67 million people in 2012. The incidence of cases occurred in developed countries, while the global burden of these cases is getting higher in developing countries (Freitas \& Weller, 2015); Ferlay et al., 2015)(Freitas \& Weller, 2015)

The initial symptoms in first-stage breast cancer patients are discomfort in the painful area, and there is no apparent lump in the breast(Cancer Helps, 2010).

Symptoms that arise at an advanced stage are a lump in the breast when touched by the hand. In contrast, when observed, the breast's shape and sizeare different from the previous one. There are eczema canker sores and nipples in the breast that cannot heal even after being treated, and there is watery discharge or pus.which comes out of the nipple, the nipple enters into the breast, and the breast's skin is wrinkled.(Mangan, 2009).

Based on the results of research by Ozmen et al. (2014),show that the symptoms in breast cancer patients are self-detected (67\%), lumps $(75.2 \%)$, pain $(13.8 \%)$, changes in the skin or nipples (5). , 0\%), nipple discharge $(5.0 \%)$, and other symptoms (3.3\%)(Ozmen et al., 2014).

According to the head of the education and training installation at Dharmis Cancer Hospital, a phenomenon that often occurs in society, especially in Indonesia, the patient comes at an advanced stage because they do not know the initial symptoms of breast cancer embarrassed to check their condition. Most of them prefer treatment to psychics before doctors (Tapan, 2005).

This is also followingRasjidi (2010) opinion that about $85 \%$ of breast cancer patients come to the hospital at an advanced stage. This will have an impact on healing the patient. If the patient arrives at an early stage, it will get faster treatment, and the patient's cure rate will be better, and the results can be maximized.

Based on data from the NTB Provincial Hospital Medical Records, since the oncology clinic's opening in August 2017, cancer patients' number has increased quite rapidly. From August to December 2017, there were 2200 cancer patient visits data, and from January to March 2018, there were 3500 visits. Where most cancer patients are breast cancer patients with an advanced stage. (Medical Record Data of NTB Provincial Hospital).

There are three types of delay in the management of cancer treatment, namely: (1) delays in sufferers, (2) late doctors, (3) delays in Hospitals (Sukardja,2002;in Hikmanti \&Fauziah., (2010). Factors that can affect breast cancer delays in terms of sufferers include (1) socioeconomic (expensive surgery), (2) education, (3) psychology (Hawari, 2007).

According to Dr. Mithcell A. Gold from Francis Delafield Hospital (1964) in Hawari (2004) suggests that there are psychological factors that hinder the arrival of patients (the reason for delay) as follows: (1) fear, (2) low self-esteem and shame, (3) never pay attention to own breasts, (4) negativistic attitude, (5) depression. (6) compulsions.

Based on the results of research fromOzmen et al. (2014)that nearly half of breast cancer patients who seek medical care within two weeks (44.6\%) of the onset of the initial symptoms of the disease, whereas (17.3\%) of patients delay seeking medical care for three months.(Ozmen et al., 2014).

Meanwhile, the factor that affects the delay in breast cancer in terms of doctor or medical staff's ignorance (Doctor delay) is the doctor or medical personnel's attitude. What should be the attitude of a general practitioner when he gets a patient with breast cancer? This doctor's perspective is critical in determining, especially if the breast disorder is still in an early stage. Those who come at an advanced stage also lie in the doctor who first discovered their early symptoms. This is because the doctor in question has "failed" in providing motivation and eliminates the fear of facing the words "surgery" so that the patient tries to do it first in his ways to seek treatment here and there to avoid surgery. After feeling hopeless and failing, go back to the doctor, and usually, things are much worse than before. (Hawari, 2007).

The factors that affect the delay in terms of the hospital (Hospital delay). In-hospital services, patients are always asked to complete files to seem slow in providing services. To get faster service, patients have to queue earlier-lack of facilities and infrastructure and less human 
resources than hospitals and a lack of cancer patient services.

The understanding of BPJS officers at the second and third level referral hospitals is not the same. The number of medicines needed by patients, but most of them are not guaranteed by BPJS Health, although guaranteed, the hospital department does not provide the drugs needed by patients. The bureaucratic way is too long to get drugs. All of this, in the end, accumulates that the service is slow, convoluted, unfriendly for BPJS Kesehatan users, in this case, cancer patients. (Gumelar, 2017).

\section{METHOD}

The type of research used is quantitative research. The research design is descriptive retrospective non-analytic, namely a research method carried out objectively to describe a situation objectively by looking back (Notoatmodjo, 2007). This research was conducted at the Oncology Poly of the NTB Provincial Hospital with 35 samples, namely stage III and IV breast cancer patients treated for the last 3 years. Primary and secondary data sources. The researchers collected data using a patient psychological questionnaire (fear, never paid attention to breasts, the patient's negative attitude). To find out the delay system, the researcher searched for the patient's medical record. Univariate and bivariate data analysis using the chi-square test with a confidence level of $95 \%$ (0.05).

\section{RESULTS AND DISCUSSION RESULTS}

Table1.Distribution of Respondents based on age and marital status in the oncology Polyclinic of the NTB Provincial Hospital in 2018

\begin{tabular}{llll}
\hline Variable & Characteristics & $\mathrm{N}$ & $\%$ \\
\hline \multirow{4}{*}{ Age } & $<35$ & 1 & 2.9 \\
& $36-45$ & 17 & 48.6 \\
& $>45$ & 17 & 48.6 \\
& Total & 35 & 100 \\
\hline \multirow{3}{*}{ Marital status } & Single & 2 & 5.7 \\
& Married & 33 & 94.3 \\
& Total & 35 & 100 \\
\hline
\end{tabular}

Sumber: Data Primer 2018

Based on the table above, the largest age category is $36-45$ and $>45$ as many as 17 people (48.6\%).Meanwhile, the largest category of marital status was married as many as 33 people $(94.3 \%)$.
Table 2. Description of Patient Delay Factors, Doctor Delays, and System Delays Affecting the Management of Treatment Delays in Women with Stage III and IV Breast Cancer at the Oncology Polyclinic of the NTB Provincial Hospital in 2018

\begin{tabular}{|c|c|c|c|}
\hline Variable & Characteristics & $\mathrm{N}$ & $\%$ \\
\hline \multicolumn{4}{|l|}{ Patient Delay } \\
\hline \multirow{4}{*}{ Education } & High & 8 & 22.9 \\
\hline & Moderate & 11 & 31.4 \\
\hline & Low & 16 & 45.7 \\
\hline & Total & 35 & 100 \\
\hline \multirow{3}{*}{ Profession } & Work & 15 & 42.9 \\
\hline & Does not work & 20 & 57.1 \\
\hline & Total & 35 & 100 \\
\hline \multirow{3}{*}{$\begin{array}{l}\text { Health } \\
\text { insurance }\end{array}$} & NPBI & 15 & 42.9 \\
\hline & PBI & 20 & 57.1 \\
\hline & Total & 35 & 100 \\
\hline \multirow{3}{*}{ Income } & $\leq 1.8$ million & 19 & 54.3 \\
\hline & $\geq 1.8$ million & 16 & 45.7 \\
\hline & Total & 35 & 100 \\
\hline \multirow{3}{*}{ Social economy } & Able & 14 & 40 \\
\hline & Not capable & 21 & 60 \\
\hline & Total & 35 & 100 \\
\hline \multirow{3}{*}{ Fright } & Afraid & 33 & 94.3 \\
\hline & Not afraid & 2 & 5.7 \\
\hline & Total & 35 & 100 \\
\hline \multirow{4}{*}{$\begin{array}{l}\text { Negative } \\
\text { attitude }\end{array}$} & $\begin{array}{l}\text { Negative } \\
\text { Attitude }\end{array}$ & 35 & 100 \\
\hline & Positive & & \\
\hline & Attitude & 0 & - \\
\hline & Total & 35 & 100 \\
\hline \multirow{4}{*}{$\begin{array}{l}\text { Patient } \\
\text { psychology }\end{array}$} & Good & 1 & 2.9 \\
\hline & Enough & 5 & 14.3 \\
\hline & Less & 29 & 82.8 \\
\hline & Total & 35 & 100 \\
\hline \multicolumn{4}{|l|}{ Late Doctor } \\
\hline \multirow{3}{*}{$\begin{array}{l}\text { Delay } \\
\text { Referral }\end{array}$} & $\leq 30$ days & 18 & 51.4 \\
\hline & $\geq 30$ days & 17 & 48.6 \\
\hline & Total & 35 & 100 \\
\hline \multirow{3}{*}{$\begin{array}{l}\text { Diagonsist } \\
\text { Delay }\end{array}$} & $\geq 30$ days & 10 & 28.6 \\
\hline & $\leq 30$ days & 25 & 71.4 \\
\hline & Total & 35 & 100 \\
\hline \multicolumn{4}{|l|}{ System Delay } \\
\hline \multirow{3}{*}{$\begin{array}{l}\text { Delay } \\
\text { Referral }\end{array}$} & $\geq 30$ days & 14 & 40 \\
\hline & $\leq 30$ days & 21 & 60 \\
\hline & Total & 35 & 100 \\
\hline \multirow{3}{*}{$\begin{array}{l}\text { Delay } \\
\text { Therapy }\end{array}$} & $\geq 20$ days & 6 & 17.1 \\
\hline & $\leq 20$ days & 29 & 82.9 \\
\hline & Total & 35 & 100 \\
\hline \multirow{3}{*}{$\begin{array}{l}\text { Administrative } \\
\text { Delays }\end{array}$} & $\geq 30$ days & 9 & 25.7 \\
\hline & $\leq 30$ days & 26 & 74.3 \\
\hline & Total & 35 & 100 \\
\hline
\end{tabular}

Sumber: Data Primer 2018 
Based on the table above, they know that delays occur in respondents with low education, namely as many as $16(45.7 \%)$. Where respondents who do not work as many as $20(57.1 \%)$. And on average, 19 people have PBI health insurance $(60 \%)$ with an income of $\leq 1.8$ million as many as $19(54.3 \%)$. Of the total, three socio-economic factors (employment, social security, income) are added and calculated, and it is known that the respondents' criteria for incapacity as much as 21 $(60 \%)$.

The table above shows that most respondents fear cancer diagnosis as much as 33 (94.3\%) and have a negative attitude towards themselves as much as 35 (100\%).

From the total of the three psychological factors are added up and calculated, and it is found that out of 35 respondents, 29 (82.8) have a psychologic deficiency.

Based on the table above, the doctor's delay factor shows that respondents who received referrals $\leq 30$ days from the examination were 18 (51.4\%), and respondents who received a diagnosis of $\leq 30$ days were 25 (71.4\%). Based on the system delay factor, it can see that respondents who received referrals $\leq 30$ days from the examination were $21 \quad(60 \%)$, respondents who received first chemotherapy $\leq$ 20 days since diagnosis was 29 (82.9\%). Respondents who received time ranges from first chemotherapy to chemotherapy second $\leq 30$ days as many as $26(74.3 \%)$.

Table 3.The Relationship Between Patient Delay Factors, Doctor Delays, and System Delays Affecting the Management of Delay in Treatment with Stage III and IV Breast Cancer at the Oncology Polyclinic of the NTB Provincial Hospital in 2018

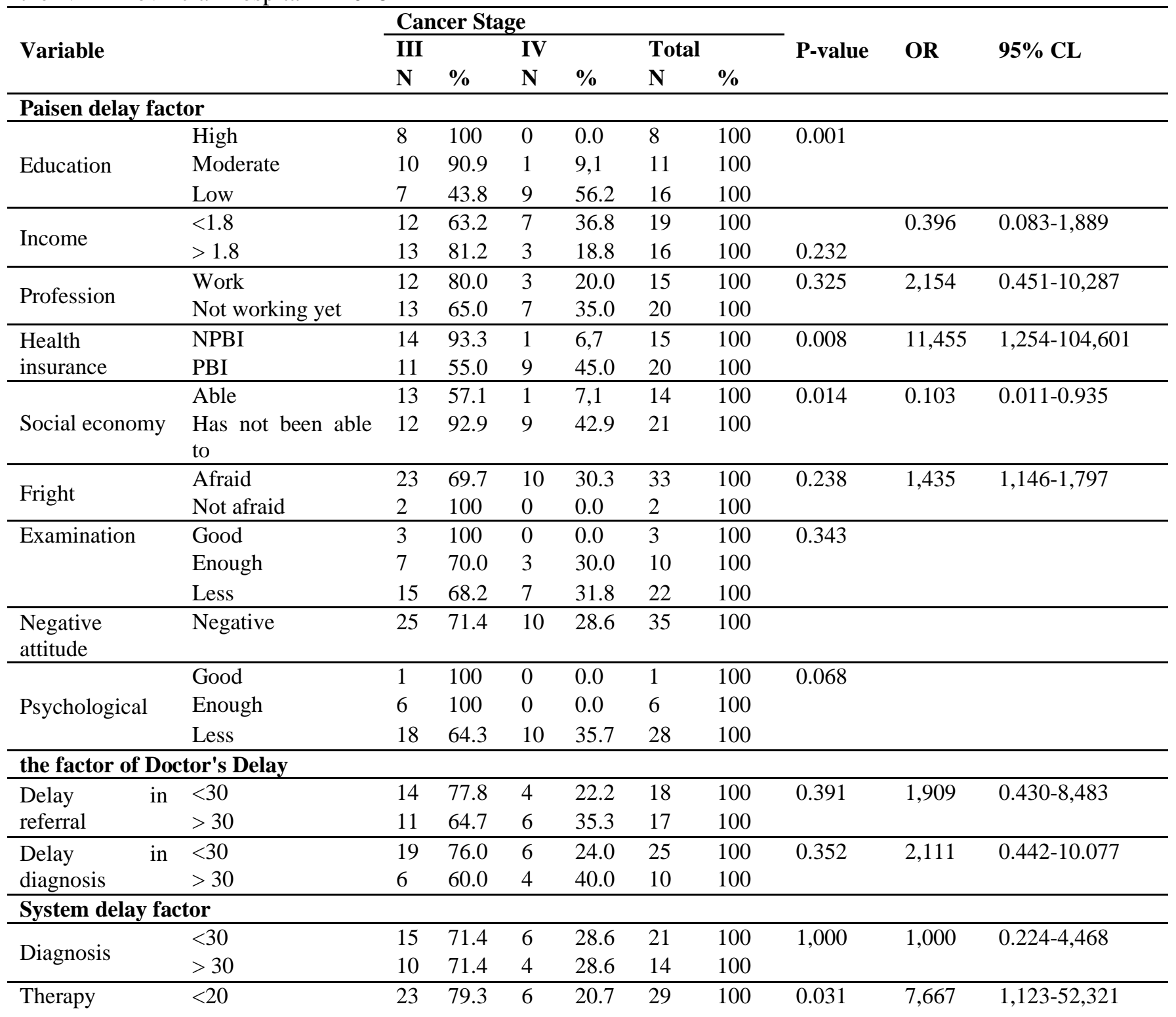




\begin{tabular}{lllllllllll}
\hline & $>20$ & 2 & 33.2 & 4 & 66.7 & 6 & 100 & & \\
\cline { 2 - 9 } Administration & $<30$ & 19 & 73.1 & 7 & 26.9 & 26 & 100 & 0.716 & 1,357 & $0.265-6,958$ \\
& $>30$ & 6 & 66.7 & 3 & 33.3 & 9 & 100 & & & \\
\hline
\end{tabular}

Sumber: Data Primer 2018

Based on the table above, the results of the relationship analysis are as follows:

a. The highest incidence of breast cancer occurred at stage III, with a moderate education levelof 10 people (90.9\%). A sig pvalue of 0.001 with $\alpha=0.05$, meaning that there is a significant relationship. $(\mathrm{p}<0.05)$

b. The highest incidence of breast cancer occurred in stage III with an income $>1.8$ as many as 13 people $(81.2 \%)$, with a sig pvalue of 0.232 with $\alpha=0.05, \mathrm{OR}=0.396$ and $95 \% \mathrm{CL}=0.083-1.889$ means that there is no significant relationship. ( $p>0.05$ )

c. The highest incidence of breast cancer occurred in stage III, who has not worked as many as 13 people $(65.0 \%)$ with a sig pvalue of 0.325 with $\alpha=0.05, \mathrm{OR}=2.154$ and $95 \% \mathrm{CL}=00.451-10.287$ means that there is no relationship significant. ( $p>0.05)$

d. The highest incidence of breast cancer occurred at stage III who participated in the NPBI type health insurance as many as 14 people $(93.3 \%)$, with a sig p-value of 0.008 with $\alpha=0.05 \mathrm{OR}=11.455$ and $95 \% \mathrm{CL}=$ 1.254-104.601 means that there is a significant relationship. $(\mathrm{p}<0.05)$

e. The highest incidence of breast cancer occurred in stage III, whose socio-economic conditions included as many as 13 people (57.1\%). A sig p-value of 0.014 with $\alpha=$ $0.05, \mathrm{OR}=0.103$ and $95 \% \mathrm{CL}=0.011-0.935$ means that there is a significant relationship. $(\mathrm{p}<0.05)$

f. The highest incidence of breast cancer occurred in the stage III fear category as many as 23 people $(69.7 \%)$ with $\alpha=0.05$, $\mathrm{OR}=1.435$, and $95 \% \mathrm{CL}=1.146-$ 1.797 ,which means that there is no significant relationship. $(p>0.05)$

g. The highest incidence of breast cancer occurred at stage III with fewer examinations as many as 15 people $(68.2 \%)$ with a sig pvalue of 0.343 with $\alpha=0.05$, meaning no significant relationship. $(p>0.05)$

h. The highest incidence of breast cancer occurred at a stage with a negative attitude as many as 25 people $(71.4 \%)$

i. The highest incidence of breast cancer occurred in stage III with less than 18 people (64.3\%) with a sig p-value of 0.068 and $\alpha=$
0.05 , meaning no significant relationship exists. (p>0.05)

j. The highest incidence of breast cancer occurred at stage III who experienced referral delay <30 days as many as 14 people (77.8\%), with a sig p-value of 0.391 with $\alpha=$ $0.05, \mathrm{OR}=1.909$ and $95 \% \mathrm{CL}=0.430-8.483$ means that there is no significant relationship. ( $p>0.05)$

$\mathrm{k}$. The highest incidence of breast cancer occurred in stage III who experienced late diagnosis <30 days as many as 19 people (76.0\%), with a sig p-value of 0.352 with $\alpha=$ 0.05 , OR $=2.111$ and $95 \% \mathrm{CL}=0.442$ 10.077 means that there is no significant relationship. ( $p>0.05)$

1. The highest incidence of breast cancer occurred in stage III who experienced late diagnosis <30 days as many as 15 people $(71.4 \%)$, with a sig p-value of 1,000 with $\alpha=$ 0.05 , OR $=1000$ and $95 \% \mathrm{CL}=0.442$ 10.077 means that there is no significant relationship. ( $p>0.05$ )

$\mathrm{m}$. The highest incidence of breast cancer occurred in stage III who experienced delayed therapy <20 days as many as 23 people (79.3\%), with a sig p-value of 0.031 with $\alpha=0.05$, OR $=7.667$ and $95 \% \mathrm{CL}=$ $1,123-52,321$ means that there isa significant relationship. $(\mathrm{p}<0.05)$

n. The highest incidence of breast cancer occurred in stage III who experienced administrative delays <30 days as many as 19 people $(73.1 \%)$, with a sig p-value of 0.716 with $\alpha=0.05, \mathrm{OR}=1.357$ and $95 \% \mathrm{CL}=$ $0.265-6,958$ means that there is no significant relationship. $(\mathrm{p}>0.05)$

\section{DISCUSSION}

Delays in the diagnosis and treatment ofbreast cancer can increase morbidity and mortality. There is a difference in the time delay between developed and developing countries. The average time delay in the United States is around 4.9 weeks(Fedewa et al., 2011)in Denmark, it is about 9.3 weeks(Thind et al., 2010), while the delay in Kenya (Maly et al., 2011), Malaysia (Sheppard et al., 2014), and India. Globally the mean delay was about 13.8 weeks (median: 10.0). (Ozmen et al., 2014). 
According to(Notoatmodjo, 2013), education can bring the broadest insight and knowledge. Because highly educated people will have higher knowledge than people with low education.

Based on the research results on educational factors, known that of the 35 respondents, the highest level of education was 16 people $(45.7 \%)$.

This study's results are from research conducted by (Hikmanti \& Fauziah, 2010), which states that primary school education is higher in breast cancer patients. Education dramatically influences one's knowledge. In this regard, learning about cancer, its causes, and risk factors can aggravate cancer, prevent it, and detect breast cancer as early as possible.

Education functions to change one's mindset, behavior, and how someone makes decisions. If the patient understands the treatment measures that give every day, it can accelerate the patient's healing of the disease (Ningsih et al., 2015).

Research conducted bySobani et al.(2012)stated that family income is related to the level of awareness related to breast cancer screening. The results of this study are by the theory put forward by Bastable (2002) in Zainab et al. (2015),

A person's social and economic level is very influential in determining health status and health behavior. If someone's income is higher, then they can make good use of health care facilities, and vice versa for those with low income. so they can not afford to buy medicine or transportation costs to go to health care(Notoatmodjo, 2013).

The level of family income is very influential in getting information about breast cancer and how to prevent it. Desanti et al. (2010) research show that the source of readily available information is electronic media. (Desanti et al., 2010).

Newcomb is a social psychologist who argues that attitude is a matter of action and not a specific motive. A positive attitude is formed from good behavior. A positive attitude significantly affects someone is acting on something, but it is due to factors from within the person himself if someone does not do something. (Notoatmodjo, 2013).

Women who have an abnormality will feel devastated, especially with patients suffering from breast cancer. They must feel afraid of death, lose control, worry, and stress because their breasts have abnormalities. The breast is an organ that is used to give breast milk to babies/children, and one of the attractions for men if the shape of the breasts is no longer attractive. (Herawati, 2015; InNingsih et al., 2015)

This is by research(Hikmanti \& Fauziah, 2010)that women diagnosed for the first time with breast cancer were mostly late in treatment because of fear as many as $87.5 \%$ (7 people) delayed treatment. People with Breast cancer have a lot of afraid, such as fear of not recovering, expensive medical costs, and fear of undergoing treatment, including surgery and chemotherapy, which lacks information. Based on the chi-square analysis, there was no relationship between afraid and delay in treatment ( $p>0.05)$.

The Doctor delay factor is divided into two elements, namely late referral and late diagnosis The delay in referral is the period from the anatomical pathology release to the first chemotherapy. The delay in diagnosis is the time from the first patient control to the anatomical biopsy/pathology.

Based on the researcher's data, the delay in inpatient treatment was not caused by the doctor's delay in diagnosis but rather the patient's fear. For example, respondent number 7 respondent was diagnosed with breast cancer on March 10, 2018 , returned to control after 72 days and agreed to do chemotherapy, namely May 21, 2018, to be precise. And based on the psychological results, the respondent got a score of 100 on the fear factor, namely the criteria afraid, the examination factor receives a score of 60 with the requirements of the examination being sufficient, and the negative attitude factor gets a score of 75 , which is having a negative attitude. This is the case with respondent number 3 , where on August 18,2015 , the patient was diagnosed with stage II breast cancer. At that time, the general surgeon referred the patient out of the area (Sanglah Hospital) because, in 2015, there were no chemotherapy facilities in the NTB area, but the patient did not do so. And on August 23, 2017, the patient was admitted through the ER at the NTB Provincial Hospital and was given chemotherapy cito on August 25, 2017.

The results of this study are also following the results of research conducted by Ristarolas (2009) in (Kartini et al., 2019)(Kartini et al., 2019) which states that the reinforcing factor does not affect treatment delay because it strengthens informants to treat their disease, namely family, friends, as well as health workers. 
All respondents were referredto the NTB Provincial Hospital after the respondent was diagnosed with breast cancer at the health center or district hospital. Incomplete facilities in cancer treatment make respondents prefer to go to the NTB Provincial Hospital, which has more complete medical equipment than other hospitals in NTB. The results of this study are by the research of Sukadja (2002) in (Hikmanti \& Fauziah, 2010)that the incomplete hospital equipment for treatment is one of the factors for the delay in the treatment of a disease, one of which is in cancer treatment.

This study's results are also in line with Ristarolas (2009) research in (Kartini et al., 2019), which states that the enabling factors that influence the delay in treatment are due to incomplete equipment from the previous hospital for treatment. Is one of the elements in the delay in treatment.

\section{BIVARIATE}

From the results of the analysis of factors associated with the late treatment of cancer treatment, there are 14 variables. Only four variables (education, health insurance, socioeconomic, and delay in therapy) and variables had no significant relationship (income, employment, fear, examination, negative attitudes, psychological, late referral, late diagnosis, diagnosis, and giving).

There is a significant relationship between education and breast cancer. The results of this study are in line with research conducted by (Marcu et al., 2016), low education significantly affects someone in delaying treatment; this causes young women to develop breast cancer and can affect a person's attitude in dealing with a disease(Marcu et al., 2016).

According to Rahayu's research in Mentawai, there is a significant relationship between education and cancer treatment choice for stage III and IV (Rahayu, 2012).

This study is in line with Wijayanti (2011)study that education has a significant effect on the delay in breast cancer treatment to health services.

The results of this study are supported by Romadani (2017) researchthat a person's lack of knowledge can lead to respondents' ignorance about cancer treatment(Dyanti \& Suariyani, 2016).

In the results of this study, most of the respondents had NBPI type health insurance. This study is not in accordance with the research of Hikmanti \& Fauziah ( 2010)that there is no significant relationship between health insurance owners and treatment delays $(\mathrm{P}>0.05)$.

Studies in the United States report that most people who do not have health insurance prefer to delay treatment compared to people who have health insurance. There is a higher mortality rate at a young age who do not have health insurance than people who have health insurance coverage(Cancer \& Disparities, 2004).

The therapy has not been completed due to the high cost of treatment and treatment that is not carried out regularly or continuously. Even though the treatment is covered by health insurance, they are not covered and still incur additional costs.

Some respondents experienced delays in treatment because the cost of cancer treatment was prohibitive. According to research conducted by Khakbazan et al., it is stated that financial pressure affects delays in breast cancer patients in treatment (Khakbazan et al., 2014). Not in accordance with the opinion of Saldana Castaneda in a literature review that the relationship between socioeconomic status and delay in treatment cannot be proven with certainty.(Unger-Saldaña \& Infante-Castañeda, 2009).

One of the factors behind the delay in cancer treatment is the socio-economic status seen from the respondents' financial ability to access health services, 0.013 times the delay in cancer treatment compared to economically well off people. This study is by research(Dyanti \& Suariyani, 2016); the results show that people who are not well off are 5.95 times at risk of delays in initial breast cancer screening than people whose socio-economic level is considered capable with a sig value. 0.003 ( $\mathrm{P}<0.05)$ (Dyanti $\&$ Suariyani, 2016).

There was a significant association between delayed therapy and stage III and IV cancers (P $<0.05)$. This is in line with research conducted byKartini et al. (2019)that one of the factors for the delay in cancer treatment management is the factor of hospitals that do not have complete medical equipment.(Kartini et al., 2019).

\section{CONCLUSION}

Based on the results of the research above, it can be concluded that there is a relationship between education, health insurance, socioeconomic factors, and delay in therapy with treatment management in patients with stage III \& IV breast cancer at the oncology polyclinic of 
the NTB Province Regional Hospital in 2018 and there is no relationship between income, employment factors, fear, examination, negative attitudes, psychological, late referral, delay in diagnosis, diagnosis, and administrative aspects with treatment management in patients with stage III \& IV breast cancer at the oncology polyclinic RSUD NTB Province in 2018

\section{REFERENCES}

American Cancer Society. (2017). About Breast Cancer. Breast Cancer Facts and Figures, 119.

https://www.cancer.org/content/dam/CRC/P DF/Public/8577.00.pdf\%0Ahttp://www.brea stcancer.org/symptoms/understand_bc/what _is_bc

Anzic, M., \& Marinko, T. (2020). Effect of Adjuvant Hormonal Therapy on the Development of Pulmonary Fibrosis after Postoperative Radiotherapy for Breast Cancer. Journal of Breast Cancer, 23(5), 449. https://doi.org/10.4048/jbc.2020.23.e48

Cancer Helps, T. (2010). Stop Kanker. Jakarta: PT Agro Media Pustaka.

Cancer, R., \& Disparities, H. (2004). New center to reduce cancer health disparities. Annals of Oncology, 11(12), 1506. https://doi.org/10.1093/oxfordjournals.anno nc.a010404

Depkes RI. (2009). Buku Saku Pencegahan Kanker Leher Rahim Dan Kanker Payudara (p. 24).

Desanti, O. I., Sunarsih, I., \& Supriyati. (2010). Persepsi Wanita Berisiko Kanker Payudara Tentang Pemeriksaan Payudara Sendiri Di Kota Semarang, Jawa Tengah. Berita Kedokteran Masyarakat, 26(3), 152-161.

Dyanti, G. A., \& Suariyani, N. L. P. (2016). Faktor-Faktor Keterlambatan Penderita Kanker Payudara dalam Melakukan Pemeriksaan awal ke Pelayanan Kesehatan. Jurnal Kesehatan Masyarakat, 11(2), 97104.

Fedewa, S. A., Edge, S. B., Stewart, A. K., Halpern, M. T., Marlow, N. M., \& Ward, E. M. (2011). Race and ethnicity are associated with delays in breast cancer treatment (2003-2006). Journal of Health Care for the Poor and Underserved, 22(1), 128-141. https://doi.org/10.1353/hpu.2011.0006

Ferlay, J., Soerjomataram, I., Dikshit, R., Eser, S., Mathers, C., Rebelo, M., Parkin, D. M., Forman, D., \& Bray, F. (2015). Cancer incidence and mortality worldwide: Sources, methods and major patterns in GLOBOCAN 2012. International Journal of Cancer, 136(5), E359-E386. https://doi.org/10.1002/ijc.29210

Freitas, A. G. Q., \& Weller, M. (2015). patiens delays and system delays in breast cancer treatment in developed and developing countries. Ciencia e Saude Coletiva, 20(10), 3177-3189. https://doi.org/10.1590/1413812320152010.19692014

Gumelar, L. A. (2017). Bersama Melawan Kanker Payudara: Yayasan Kanker Payudara Indonesia.

Hawari, D. (2007). Manajemen Stres, Cemas, dan depresi. Balai Penerbit. EGC. Jakarta.

Hikmanti, A., \& Fauziah, H. N. (2010). Analisis Faktor-faktor yang mempengaruhi Keterlambatan Pengobatan pada wanita penderita kanker payudara.

Kartini, K., Lubis, N. L., \& Moriza, T. (2019). Analisis Faktor Yang Mempengaruhi Keterlambatan Pengobatan Pada Wanita Penderita Kanker Payudara Di Rumah Sakit Umum Daerah Simeulue Tahun 2018. Jurnal Info Kesehatan, 17(1), 16-34. https://doi.org/10.31965/infokes.vol17.iss1. 240

Khakbazan, Z., Taghipour, A., Roudsari, R. L., \& Mohammadi, E. (2014). Help seeking behavior of women with self-discovered breast cancer symptoms: A metaethnographic synthesis of patient delay. PLoS ONE, 9(12), 1-24. https://doi.org/10.1371/journal.pone.011026 2

Maly, R. C., Leake, B., Mojica, C. M., Liu, Y., Diamant, A. L., \& Thind, A. (2011). What influences diagnostic delay in low-income women with breast cancer? Journal of Women's Health, 20(7), 1017-1023. https://doi.org/10.1089/jwh.2010.2105

Mangan, Y. (2009). Cara Sehat Mencegah dan Mengatasi Kanker. Jakarta: Agromedia pustaka.

Marcu, A., Lyratzopoulos, G., Black, G., Vedsted, P., \& Whitaker, K. L. (2016). Educational differences in likelihood of attributing breast symptoms to cancer: a vignette-based study. Psycho-Oncology, 3178 , 1191-1197. https://doi.org/10.1002/pon.4177

Ningsih, S. f, Karim, D., \& Sabrian, F. (2015). Efektivitas terapi emotional freedom tehnique (EFT) terhadap kecemasan pasien 
kanker payudara stadium II dan III. Cybrarians Journal, 2(37), 1-31. https://doi.org/10.12816/0013114

Notoatmodjo, S. (2007). Promosi Kesehatan Dan Ilmu Perilaku. Jakarta: Rineka Cipta.

Notoatmodjo, S. (2013). Konsep Perilaku dan Perilaku Kesehatan. In: Notoatmodjo S. Promosi Kesehatan dan Perilaku Kesehatan. Jakarta: PT Rineka Cipta;

Ozmen, V., Boylu, S., Ok, E., Canturk, N. Z., Celik, V., \& Kapkac, M. (2014). Factors affecting breast cancer treatment delay in Turkey : A study from Turkish Federation of Breast Diseases Societies Factors affecting breast cancer treatment delay in Turkey: a study from Turkish Federation of Breast Diseases Societies. August. https://doi.org/10.1093/eurpub/cku086

Rahayu, D. A. (2012). Faktor-faktor yang berhubungan dengan pemilihan pengobatan tradisional di wilayah kerja Puskesmas Muara Siberut Kecamatan Siberut Kabupaten Kepulauan Mentawai tahun 2012. Skripsi, 1-13.

Rasjidi, I. (2010). Epidemologi Kanker Pada Wanita. Jakarta: CV Sagung Seto;

Romadani, D. I. (2017). Gambaran Penderita Kanker Serviks yang Terlambat Melakukan Deteksi Dini Kanker Serviks.

Sheppard, V. B., Ph, D., Isaacs, C., Luta, G., Ph, D., Shawna, C., Boisvert, M., Harper, F. W. K., Ph, D., Smith, K., Horton, S., Liu, M. C., Jennings, Y., Hirpa, F., Snead, F., \& Mandelblatt, J. S. (2014). Initiation: The Role of the Patient-Provider Relationship. 139(1), 207-216. https://doi.org/10.1007/s10549-013-25203.Narrowing

Sobani, Z., Saeed, Z., Baloch, H. N., Majeed, A., Chaudry, S., \& Sheikh, A. (2012). Students , Corner Original Article Knowledge attitude and practices among urban women of Karachi , Pakistan , regarding breast cancer. J Pak Med Assoc, 62(11), 12591264.

Tapan, E. (2005). Kanker, Antioksidan, dan Terapi Komplementer. Jakarta: PT Elex Media Komputindo.

Thind, A., Hoq, L., Diamant, A., \& Maly, R. C. (2010). Satisfaction with care among lowincome women with breast cancer. Journal of Women's Health, 19(1), 77-85. https://doi.org/10.1089/jwh.2009.1410

Unger-Saldaña, K., \& Infante-Castañeda, C. (2009). Delay of medical care for symptomatic breast cancer: A literature review. Salud Publica de Mexico, 51(SUPPL.2).

https://doi.org/10.1590/S003636342009000800018

Wijayanti, N. K. (2011). Faktor yang mempengaruhi keterlambatan penderita kanker payudara dalam memeriksakan diri kepelayanan kesehatan. 11(2), 10-14. https://doi.org/10.16194/j.cnki.31$1059 / \mathrm{g} 4.2011 .07 .016$

Zainab, Saleh, A., \& Idris, I. (2015). Hubungan Pengetahuan, Motivasi, Self Efficacy dengan Penerapan Peran Perawat sebagai Health Educator di Ruang Inap RSUD Kab . Wajo. Kesehatan Kabupaten Majene Manajemen Keperawatan Fakul. 